\title{
Depositional architecture, provenance, and tectonic/eustatic modulation of Miocene submarine fans in the Shikoku Basin: Results from Nankai Trough Seismogenic Zone Experiment
}

\author{
Kevin T. Pickering \\ Department of Earth Sciences, University College London, Gower Street, London, WC1E 6BT, UK \\ (ktpickering@ucl.ac.uk)
}

\section{Michael B. Underwood}

Department of Geological Sciences, University of Missouri, 101 Geology Building, Columbia, Missouri, USA

\section{Sanny Saito}

Institute for Research on Earth Evolution, Japan Agency for Marine-Earth Science and Technology, Yokosuka, Japan

\section{Hajime Naruse}

Department of Geology E Mineralogy, Kyoto, Japan

\section{Steffen Kutterolf}

IFM-GEOMAR, Leibniz Institute of Marine Sciences at the University of Kiel, Kiel, Germany

\section{Rachel Scudder}

Department of Earth Sciences, Boston University, Boston, Massachusetts, USA

\section{Jin-Oh Park}

Atmosphere and Ocean Research Institute, The University of Tokyo, Chiba, Japan

\section{Gregory F. Moore}

Department of Geology and Geophysics, University of Hawaii at Manoa, Honolulu, Hawaii, USA

\section{Angela Slagle}

Lamont-Doherty Earth Observatory of Columbia University, Palisades, New York, USA

[1] Seismostratigraphy, coring, and logging while drilling during Integrated Ocean Drilling Program Expeditions 319, 322, and 333 (Sites C0011/C0012) show three Miocene submarine fans in the NE Shikoku Basin, with broadly coeval deposits at Ocean Drilling Program Site 1177 and Deep Sea Drilling Project Site 297 (NW Shikoku Basin). The sediment dispersal patterns have major implications for paleogeographies at that time. The oldest, finer-grained (Kyushu) fan has sheet-like geometry; quartz-rich flows were fed mostly from an ancestral landmass in the East China Sea. During prolonged hemipelagic mud deposition at C0011-C0012 ( 12.2 to 9.1 Ma), sand supply continued at Sites 1177 and 297. Sand delivery to much of the Shikoku Basin halted during a phase of sinistral strike slip to oblique plate motion, after which the Daiichi Zenisu Fan ( 9.1 to $8.0 \mathrm{Ma})$ was fed by submarine channels. The youngest fan (Daini Zenisu; $\sim 8.0$ to $7.6 \mathrm{Ma}$ ) has sheet-like geometry with thick-bedded, 
coarse-grained pumiceous sandstones. The pumice fragments were fed from a mixed provenance that included the collision zone of the Izu-Bonin and Honshu Arcs. The shift from channelized to sheet-like flows was favored by renewal of relatively rapid northward subduction, which accentuated the trench as a bathymetric depression. Increased sand supply appears to correlate with long-term eustatic lowstands of sea level. The stratigraphic position and 3-D geometry of the sandbodies have important implications for subduction-related processes, including the potential for focused fluid flow and fluid overpressures above and below the plate boundary fault: In sheet-like sands, pathways for fluid flow have greater horizontal permeability compared with those in channel sands.

Components: 11,100 words, 8 figures, 1 table.

Keywords: NanTroSEIZE; Miocene; submarine fans; strike slip; eustatic sea level.

Index Terms: 3036 Marine Geology and Geophysics: Ocean drilling.

Received 1 November 2012; Revised 1 March 2013; Accepted 2 March 2013; Published 10 June 2013.

Pickering, K. T., M. B. Underwood, S. Saito, H. Naruse, S. Kutterolf, R. Scudder, J.-O. Park, G. F. Moore, and A. Slagle (2013), Depositional architecture, provenance, and tectonic/eustatic modulation of Miocene submarine fans in the Shikoku Basin: Results from Nankai Trough Seismogenic Zone Experiment, Geochem. Geophys. Geosyst., 14, 1722-1739, doi:10.1002/ggge.20107.

\section{Introduction}

[2] Integrated Ocean Drilling Program (IODP) Expedition 322 represents one part of the multistage project called the Nankai Trough Seismogenic Zone Experiment (NanTroSEIZE). The fundamental goal of NanTroSEIZE is to create a distributed observatory spanning the updip limit of the seismogenic and tsunamigenic behavior along the Nankai Trough subduction boundary, positioned at a location where great earthquakes are known to occur [Tobin and Kinoshita, 2006a, 2006b]. The network of NanTroSEIZE boreholes and observatories will allow scientists to monitor hydrogeologic and geodetic behavior of the subduction megathrust and the megasplay fault (a major out-of-sequence fault seaward of the Kumano fore-arc basin), as well as the aseismic-seismic transition of the fault system. To accomplish this goal, several key components of the plate boundary system must be investigated, starting with the presubduction inputs of sediment and oceanic basement, moving landward into the shallow plate interface, and finally drilling to depths where earthquakes occur.

[3] The purpose of this paper is to document the principal deep marine clastic systems (submarine fans) discovered during IODP Expedition 322 that accumulated in the northern Shikoku Basin during the middle and late Miocene and to interpret their evolution in the context of the likely plate tectonic framework at that time.
[4] A better understanding of the lithostratigraphic units, how they were deposited, and their networks of sediment dispersal is important for deductions regarding parameters that affect fault slip behavior. The stratigraphic architecture of sandbodies, for example, may influence where fluid flow is focused (e.g., through high-permeability sheets or meandering shoestrings) and where excess pore water pressure might build up (e.g., at lateral pinch-outs of depositional lobes) [Bredehoeft et al., 1988; Underwood, 2007]. At the same time, the depositional setting of the Shikoku Basin is unusual from the global perspective of marine sedimentology because the basin formed on the back-arc side of an intraoceanic subduction zone (Izu-Bonin), but strata are subducting beneath a continental arc: It is more typical to find subduction only in the forearc setting. The basin's history of sedimentation, therefore, has been affected by a combination of basement relief, volcanic activity along two sides of the basin, reorganization of the plate boundary, episodes of collision between the Izu-Bonin and SW Japan (Honshu) Arcs, and subduction-driven uplift of the Japanese hinterland [Underwood and Fergusson, 2005; Ike et al., 2008a, 2008b]. This complexity sets the subduction inputs to the Nankai Trough apart from such examples as the Cascadia Basin and the Chile Trench, where subduction occurs only in the fore-arc region [Underwood and Moore, 1995; Underwood, 2007]. It also challenges the generic paradigm of progressive thickening and coarsening upward as the subducting oceanic plate 
moves closer to the subduction front [Piper et al., 1973], because the incoming plate already contains a thick pile of coarse clastics before entering the trench environment.

[5] Another question to consider when attempting to understand the stratigraphy of subduction inputs is whether or not the effects of eustatic sea level fluctuations [cf. Haq et al., 1987] can be recognized through the strong overprints of local and regional tectonics. If so, then some of the simple expectations regarding facies relations in ancient subduction complexes need to be broadened.

\section{Origin of the Shikoku Basin}

[6] The Shikoku Basin lithosphere formed due to back-arc rifting and seafloor spreading in the eastern part of the Philippine Sea plate between 30 and $15 \mathrm{Ma}$ [Watts and Weissel, 1975; Kobayashi and Nakada, 1979; Taylor, 1992; Okino et al., 1999; Sdrolias et al., 2004]. The Kyushu-Palau Ridge separates the young Shikoku Basin (eastern Philippine Sea plate) from the 40 to $60 \mathrm{Ma}$ West Philippine Basin (western Philippine Sea plate) lithosphere. The Kyushu-Palau Ridge is a remnant Eocene-Oligocene arc that split away from the Izu-Bonin-Mariana Arc during Shikoku Basin rifting. These tectonic events influenced the position and nature of the triple junction between the Pacific plate, Philippine Sea plate, and Eurasian plate (or Amurian subplate). The Kinan seamount chain represents the vestiges of the extinct spreading center in the Shikoku Basin.

[7] The Neogene history of the Shikoku Basin has been interpreted by Kano et al. [1991] and Taira [2001] to have involved six main tectonic events: (1) rifting of the paleo-Izu-Bonin Arc and opening by seafloor spreading of the Shikoku Basin (25 to $15 \mathrm{Ma}$ ), (2) rifting of the paleo-SW Japan (Honshu) continental arc and spreading of the Japan Sea basin (22 to $15 \mathrm{Ma}$ ), (3) widespread, near-trench igneous activity 17 to $12 \mathrm{Ma}$ in SW Honshu, (4) initiation of subduction of the Philippine Sea plate and collision of the Izu-Bonin Arc against the SW Japan (Honshu) Arc at $15 \mathrm{Ma}$, (5) a main phase of subduction of the Philippine Sea plate beginning at $8 \mathrm{Ma}$, and (6) collision of the Kuril fore-arc sliver and formation of the Hidaka mountain belt beginning at 15 Ma. Kimura et al. [2005] provided a detailed summary of the Tertiary magmatic processes linked with the plate tectonic history of the SW Japan (Honshu) Arc. They broadly followed the interpretations of Taira [2001], also invoking
Paleogene subduction of the Kula and Pacific plates beneath the eastern margin of Eurasia, followed by a brief episode of transform faulting to allow the Shikoku Basin to open at 27 to 15 Ma. Kimura et al. [2005] also reiterated evidence for subsequent opening of the Japan Sea back-arc basin in middle Miocene time [e.g., Otofugi et al., 1985], which caused Japan to break away from Eurasia, and SW Japan rotated clockwise $\sim 45^{\circ}$ as it drifted south (17 to $15 \mathrm{Ma}$ ). Southward drift required subduction of the Philippine Sea plate beneath SW Japan, leading to the formation of a magmatic arc, with subduction of the hot Shikoku Basin lithosphere and spreading ridge resulting in anomalous neartrench volcanism between 17 and $12 \mathrm{Ma}$ [Hibbard and Karig, 1990].

[8] Recent plate tectonic reconstructions by Mahony et al. [2011], which use the published finite rotation poles from Gaina and Müller [2007] for the Philippine Sea plate relative to Eurasia for the past $15 \mathrm{Ma}$, are incorporated into this paper. They suggest that prior to $15 \mathrm{Ma}$, the Pacific plate subduction dominated Kyushu tectonics and that from 15 to $6 \mathrm{Ma}$, the evolving relative plate motions shifted the triple junction between the Pacific plate, Philippine Sea plate, and southwest Japan northward, so that the Philippine Sea plate was subducted beneath Kyushu. The lack of subduction-related volcanism on Kyushu from 10 to $6 \mathrm{Ma}$ was attributed to shallow subduction of the young Shikoku Basin lithosphere. By at least 6 to $5 \mathrm{Ma}$, changes in the Philippine Sea plate motion led to more rapid, nearly trench normal, subduction beneath Kyushu. Their model also favors the initial collision between the Izu-Bonin Arc with the SW Japan (Honshu) Arc occurring at $\sim 8$ to $6 \mathrm{Ma}$, rather than the more widely accepted date of $\sim 15 \mathrm{Ma}$ [e.g., Tamura et al., 2010; Tani et al., 2010; Yamazaki et al., 2010]. The plate reconstructions and computer simulations of Hall [2002, 2012] also show considerable left-lateral (and strike slip) motion and collision of the Izu-Bonin and Honshu Arcs between 10 and $5 \mathrm{Ma}$. There does, however, appear to be compelling evidence for collision and accretion of some crustal block at about 15-17 Ma associated with Mio-Pliocene sedimentary basins forming in the Izu-Honshu collision zone [e.g., Soh et al., 1991] and the intrusion of the Kofu granitic complex and Tanzawa tonalite [Tamura et al., 2000; Tani et al., 2010]. Perhaps, this was not the Izu-Bonin Arc in a strict sense but either a noncontiguous, possibly younger, volcanic arc or some other bathymetric high [cf. Ali and Moss, 1999; Takahashi and Saito, 1997]. Others have proposed a separate "Mineoka plate" to account for the obduction of the 
Mineoka ophiolite immediately prior to Izu-Honshu Arc collision [Ogawa et al., 1985; Ogawa and Taniouchi, 1988]. It is interesting to note that the present northern part of the Izu-Bonin Arc contains $\sim 50 \mathrm{Ma}$ arc crust, perhaps suggesting that it may include the remnants of such a ridge that collided at $\sim 15-17 \mathrm{Ma}$.

[9] Regardless of the details, reorganization of the plate boundary must have influenced rates and pathways of sediment delivery throughout the regional system, including the Shikoku Basin. Coring during Expedition 322 provided a wealth of new evidence to improve such reconstructions. Sediments of the Shikoku Basin and Nankai trench wedge are particularly important because they are the inputs to the Nankai subduction factory [Underwood, 2007]. Significant along-strike variations in lithostratigraphy can be seen by comparing stratigraphic sections at Site 1177 (Ashizuri transect); Sites 1173, 1174, and 808 (Muroto transect); and Sites C0011 and C0012 (Kumano transect). As such, changes in lithology, mineralogy, geochemistry, and 3-D facies architecture will influence the mechanical and hydrogeological behavior of the accretionary prism and the plate boundary fault. Better predictions about the types and distribution of lithologies at depth contribute to improved forecasting of fluid pathways and fluid pressures within the offscraped and subducting sedimentary units. This paper concentrates on sandy turbidite sedimentation during the Miocene. Those deposits possess the greatest likelihood for directing fluid flow through high-permeability conduits.

\section{Methods}

[10] In this paper, we present an overview of the sedimentology and lithostratigraphy from IODP Sites C0011 and C0012, supplemented with Deep Sea Drilling Project (DSDP)/Ocean Drilling Program (ODP)/IODP drill sites in the vicinity (Figure 1). Specifically, we have used the sediment petrography, age data based on micropaleontology and paleomagnetism, stratigraphy, and logging while drilling (LWD) data from these drill sites, together with seismic profiles that cross Sites C0011 and C0012 [Underwood et al., 2010; Expedition 333 Scientists, 2011]. Older stratigraphic data are from DSDP Site 297 [Harrold and Moore, 1975; Karig et al., 1975] and ODP Site 1177 [Moore et al., 2001a]. These four locations are

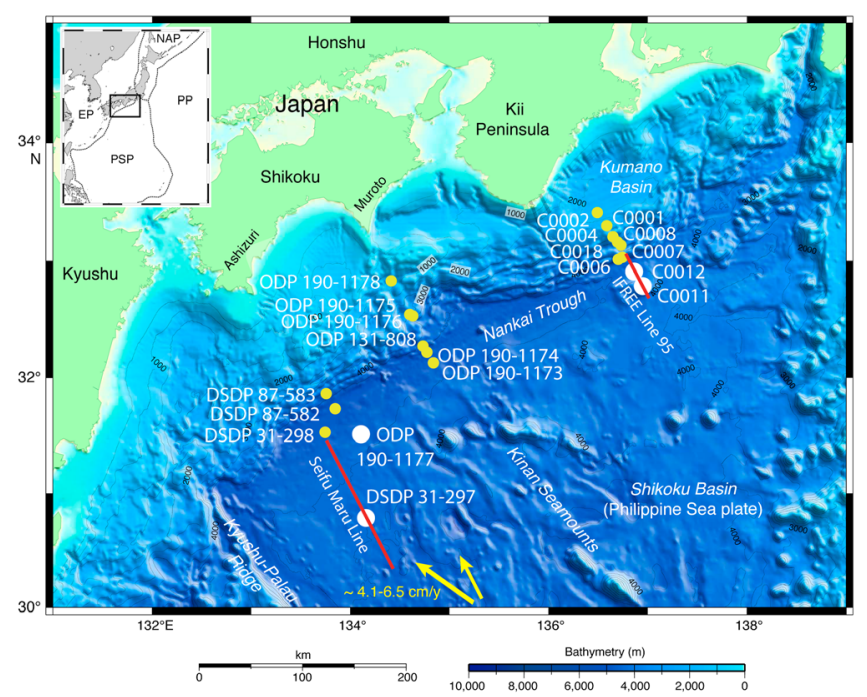

Figure 1. Bathymetric map, Nankai Trough off SW Japan showing position of DSDP/ODP/IODP sites. Sites referred to in this paper $(\mathrm{C} 0011, \mathrm{C} 0012,1177$, and 297) are shown with a larger white dot. Arrow $=$ convergence direction between Philippine Sea plate and Japan. Previous transects of Nankai Trough were positioned off Ashizuri and Muroto Peninsulas of Shikoku. EP=Eurasian plate; PP=Pacific plate; PSP = Philippine Sea plate; $\mathrm{NAP}=$ North American plate. Contours are in meters below sea surface. Red line shows Line 95 from Institute for Frontier Research on Earth Evolution (IFREE) mini-3-D seismic survey [Park et al., 2008], interpreted in Figure 4a, and Seifu Maru seismic line [after Karig et al., 1975, Figure 6]. The Kinan seamount chain represents the approximate axis of the extinct spreading center in the Shikoku Basin and divides it into western and eastern sectors. Ashizuri, Muroto, and Kii Peninsulas are shown, from which the three corresponding drill transects approximately orthogonal to the Nankai Trough axis are named. 
the only drill sites for which Shikoku Basin in situ data exist. We note that age dating for DSDP Site 297 and ODP Site 1177, however, is relatively poor when compared with that from IODP Sites C0011 and C0012. Detailed methods for all relevant shipboard analyses are described by Expedition 322 Scientists [2010].

\section{IODP Expeditions $322 \& 333$}

[11] IODP Expeditions 322 and 333 were designed to document the characteristics of the incoming sedimentary strata and upper igneous basement prior to their arrival at the subduction front [Saito et al., 2009; Underwood et al., 2010; Expedition 333 Scientists, 2011]. During IODP Expedition 322, coring was conducted at two sites in the Shikoku Basin on the subducting Philippine Sea plate (Figure 1). Site C0011 is located on the northwest flank of a prominent bathymetric high, the Kashinosaki Knoll, and Site C0012 is located near the crest of the knoll. Kashinosaki Knoll is located $\sim 100 \mathrm{~km}$ southeast of the Kii Peninsula and is $\sim 150-200 \mathrm{~km}$ west of the Izu-Bonin Arc [Ike et al., 2008a]. When seamounts and other bathymetric highs are subducted, they can cause significant deformation of the overriding plate and may act as asperities deeper in the seismogenic zone [Cloos, 1992; Scholz and Small, 1997; Bilek et al., 2003; Bilek and Lay, 2002]. When Kashinosaki Knoll collides with the accretionary prism in about 1 Myr, the associated variations in sediment type and thickness from flanks to summit will likely result in local variations in prism deformation [Ike et al., 2008a]. Due to operational failures and insufficient allocation of drilling time, Expedition 322 recovered an incomplete stratigraphic record from Sites C0011 and C0012. Intervals of the upper Shikoku Basin were cored using hydraulic piston coring system (HPCS) during Expedition 333 [Expedition 333 Scientists, 2011]. LWD was conducted at Site C0011 using contingency time during IODP Expedition 319, immediately prior to Expedition 322 [Saffer et al., 2009].

\section{Lithologic Units}

[12] Five lithologic units were identified at Site C0011 and six at Site C0012, based on sediment composition, sediment texture, and sedimentary structures [Underwood et al., 2010; Expedition 333 Scientists, 2011]. Unit I (Figure 2 and Table 1) consists of silty clay with intercalations of fine to coarse volcanic ash, typically with unaltered glass shards. The hemipelagic/pyroclastic facies ranges in age from Quaternary to late Miocene (0 to $7.8 \mathrm{Ma})$. Strata at Site C0012 were divided into three subunits by Expedition 333 Scientists [2010] on the basis of variations in lithification, alteration, and abundance of discrete volcanic ash layers (Figure 2). The deposition of Unit I occurred predominantly by hemipelagic settling of suspended sediment [Expedition 333 Scientists, 2010].

[13] An abrupt change in lithology occurs at $\sim 347$ meters below seafloor (mbsf) (C0011) and $\sim 150 \mathrm{mbsf}$ (C0012) with the appearance of tuffaceous sandstone and heterolithic gravel and sandstone. This change marks the Unit I/II boundary. Unit II (Figure 2 and Table 1) is characterized by coarse beds with sharp and well-defined upper and lower boundaries, separated by indurated mudstone. Unit II is late Miocene in age ( 7.6 to $9.1 \mathrm{Ma}$ at C0011 and $\sim 7.8$ to $9.4 \mathrm{Ma}$ at C0012). Point counts within these sandstone packages show that pyroclasts, magmatic crystals, and volcaniclastics prevail over sedimentary and metamorphic rock fragments and detrital minerals (Figure 3). The upper package (Unit IIa) at Site C0011 (340-377 mbsf) contains tuffaceous sandstones, whereas the lower sand-rich interval (Unit IIb, 377-479 mbsf) contains volcaniclastic sandstone and dark gray siltstone [Underwood et al., 2010]. The distinction between tuffaceous and volcaniclastic sandstones is based on the abundance of pumice and volcanic glass shards (Figure 3). The tuffaceous sandstones are composed of $>25 \%$ pyroclasts, with magmatic minerals showing relative abundances of plagioclase $>$ pyroxene $>$ amphibole. The volcanic glass appears very fresh, with pumiceous glass as the dominant component. The siliciclastic component is mainly chert, altered tuff, siltstone, and sandstone. The volcaniclastic sandstones contain $>25 \%$ volcaniclastic grains and $<25 \%$ pyroclastic grains. These sandstones have large proportions of minerals, with relative abundances of plagioclase pyroxene $>$ quartz $>$ amphibole. The quartz content is typically between $2 \%$ and $6 \%$, most of which is chert. Additionally, there are large amounts of sedimentary lithic grains (siltstone, sandstone, and chert).

[14] Unit II also contains chaotic intervals, or mass transport deposits (MTDs), of intermixed volcaniclastic sandstone and bioturbated silty claystone. At Site C0012 (Figure 2 and Table 1), two MTDs were recovered that are 0.3 and $3.1 \mathrm{~m}$ thick (150.86-151.17 and 178.00-181.10 mbsf). The broken strata occur with folding, thinning, and attenuation of primary bedding, probably deformed by gravitational sliding on the relatively steep north facing slopes of the Kashinosaki Knoll. 

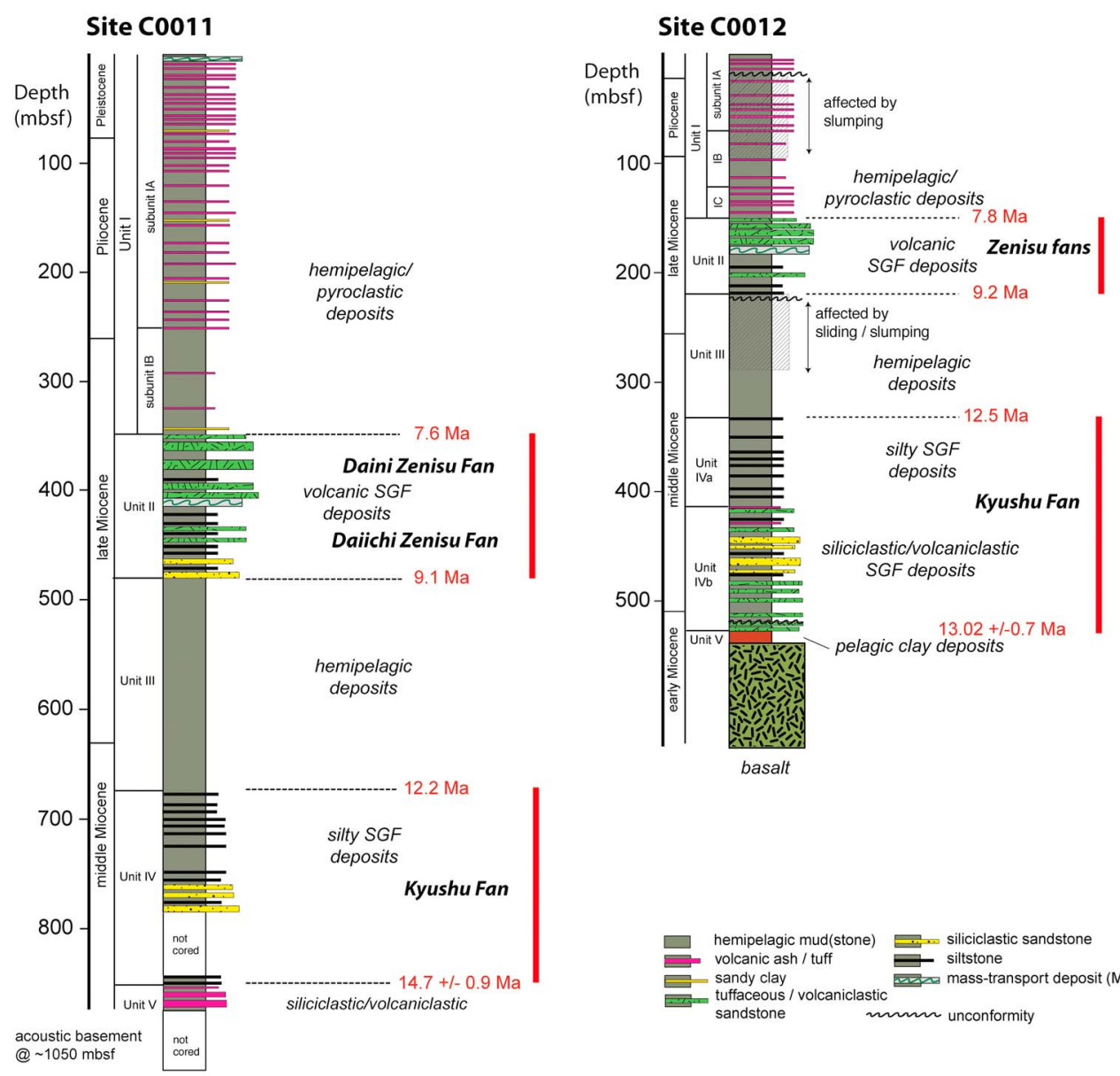

Figure 2. Lithologic columns for IODP Sites C0011 and C0012 drilled in the vicinity of Kashinosaki Knoll, NE Shikoku Basin, showing IODP Sites C0011 and C0012, based on results from Expeditions 322 and 333 [Underwood et al., 2010; Expedition 333 Scientists, 2011]. See text for explanation of the Kyushu and Zenisu submarine fans. $\mathrm{SGF}=$ sediment gravity flow, including turbidity current. Also, see Table 1 for summary of lithologic units. Note, at Site C0012, unlike at Site C0011, the two Zenisu Fans are not separately defined.

Smear slide petrography demonstrates that the sandstone fragments in the MTDs are mixtures of primary eruptive products and reworked pyroclastic and sedimentary rock fragments [Underwood et al., 2010].

[15] Unit III (Figure 2 and Table 1) is a hemipelagic facies characterized by bioturbated silty claystone. Secondary lithologies include lime mudstone and calcareous claystone. The mudrocks are middlelate Miocene in age ( 9.1-12.2 Ma at C0011 and $\sim 9.4-12.7 \mathrm{Ma}$ at $\mathrm{C} 0012$ ), and the unit thins from $194.92 \mathrm{~m}$ at Site C0011 to $112.00 \mathrm{~m}$ at Site C0012. At Site C0012, the deposits include an interval at least $15.2 \mathrm{~m}$ thick with steeply inclined bedding, typically at an angle of $40^{\circ}$ to $45^{\circ}$. From seismic evidence and core-scale deformation structures at Site C0012, this disruption appears to be associated with rotational normal faulting on the north inclined flank of Kashinosaki Knoll.
Nannofossil datums also suggest an angular unconformity near the top of this interval with a hiatus of $\sim 1$ Myr. The rate of hemipelagic sedimentation (uncorrected for compaction) at Site C0011 changed from $3.9 \mathrm{~m} / \mathrm{kyr}$ to $7.7 \mathrm{~m} / \mathrm{kyr}$ at $\sim 11 \mathrm{Ma}$ [Underwood et al., 2010].

[16] The lower boundary of the hemipelagic facies is defined by the appearance of dark gray clayey siltstone (mud turbidites). Unit IV (Figure 2 and Table 1) consists mainly of bioturbated mudstone with interbeds of normally graded siltstone and fine-grained siliciclastic sandstone. Wood fragments are common, as are detrital grains of polycrystalline quartz and metamorphic rock fragments. Unit IV is middle Miocene in age ( 12.2-14.0 Ma at Site C0011 and $>12.7-13.5 \mathrm{Ma}$ at Site C0012). This interval thins out against the flanks of Kashinosaki Knoll (Figure 1). The coarser interbeds are interpreted as sediment gravity flow (SGF) deposits (e.g., turbidites; 


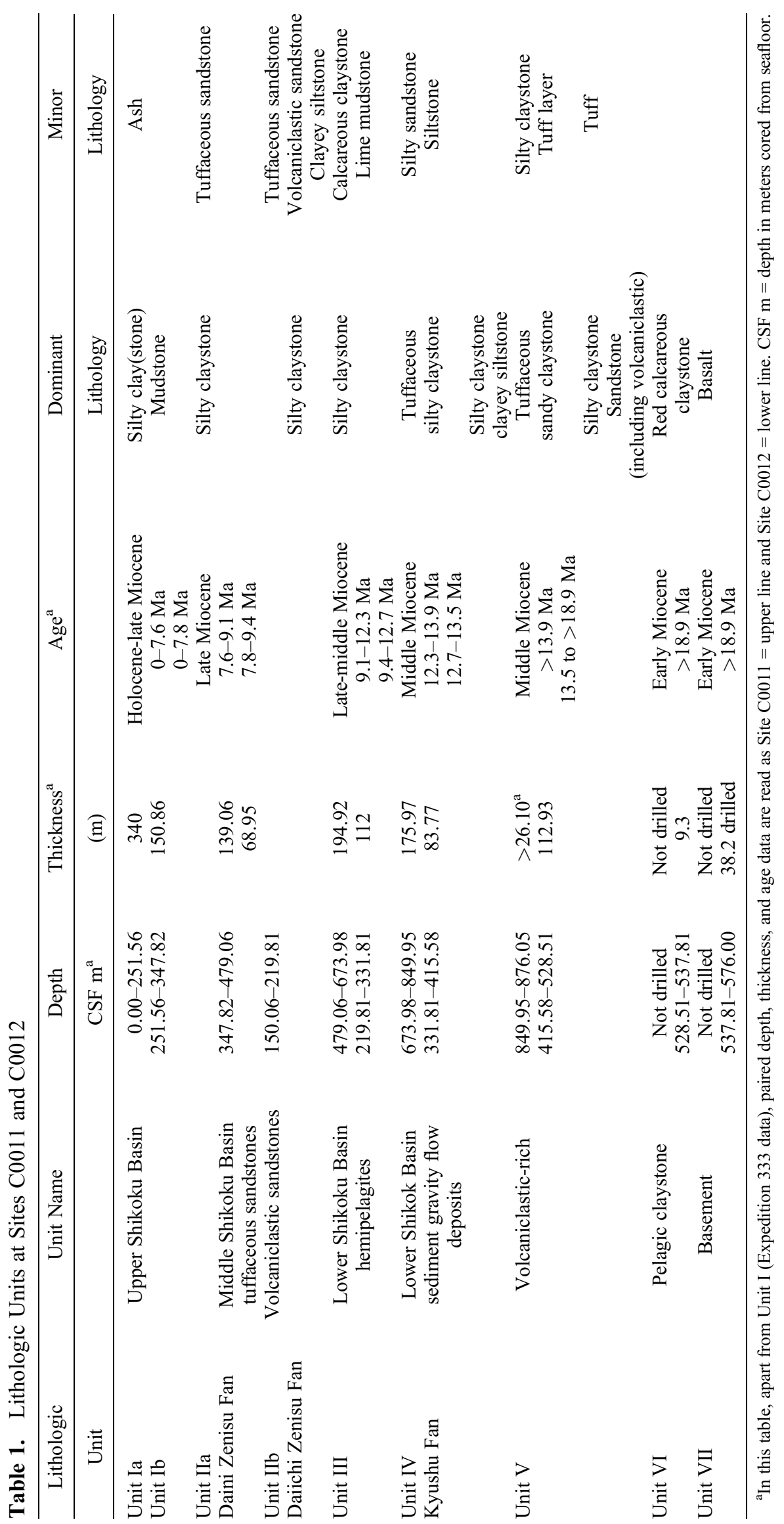



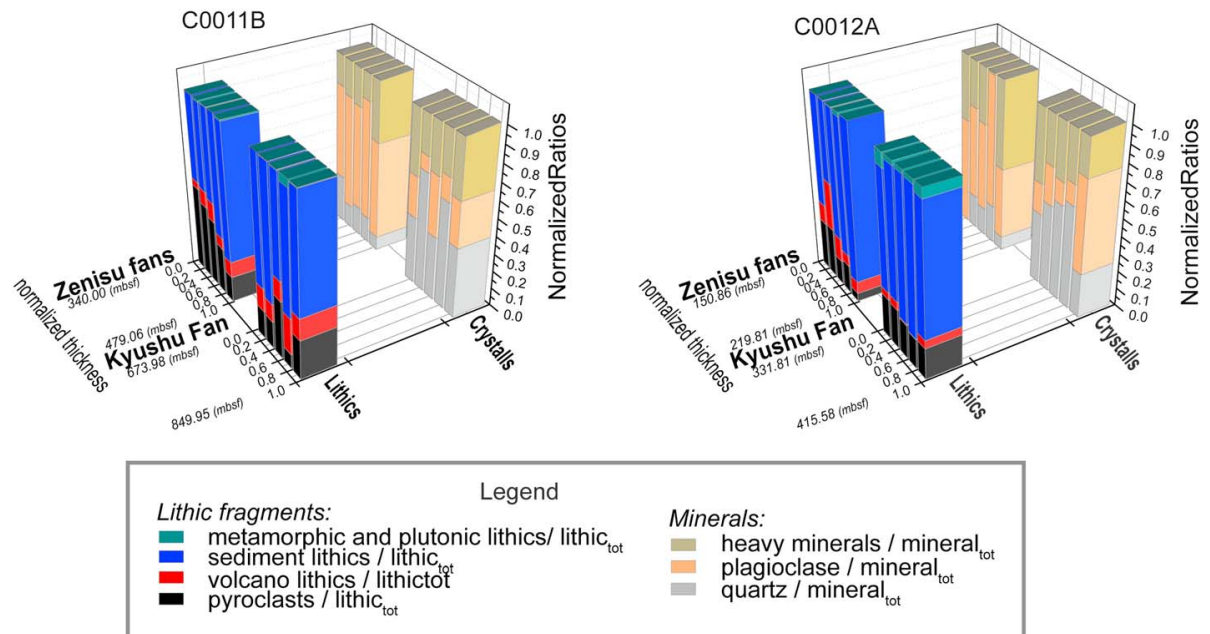

Figure 3. Summary petrography of volcanic sandstones to show different compositions of Kyushu and Zenisu Fan sandstones at both Sites C0011 and C0012. Raw data for these plots are provided in the supporting information. See Figure 2 for stratigraphic position of the submarine fans.

see Middleton and Hampton [1973] for definition of SGF deposits).

[17] Unit V (Figure 2 and Table 1) consists of tuffaceous sandy mudstone and sandstone, with minor amounts of tuff. Because of poor recovery and technical failures at Site C0011, the age of Unit $\mathrm{V}$ is poorly constrained within the middle Miocene. The correlation of units from flank to crest of Kashinosaki Knoll is further complicated by the occurrence of a major unconformity (see below). Fission track data suggest that detrital source rocks for the top of the Unit V at Site C0011 were $14.7 \pm$ $0.9 \mathrm{Ma}$, whereas detrital sources for the base of Unit V at Site C0012 were $13.02 \pm 0.7 \mathrm{Ma}$ (Saito, unpublished data). Evident from major element compositions (supporting information) ${ }^{1}$, the tuffs at Site C0011 are chemically correlative with the thick rhyolitic tuffs that were recovered at Site 808 from beneath the toe of the accretionary prism along the Muroto transect of the Nankai Trough (Figure 1); those strata yielded an age of $\sim 13.6$ Ma [Taira et al., 1992]. The fission track data suggest that the detrital sources for the upper deposits of Unit V (Site C0011) were older than the source rocks that supplied sediment to the base of Unit V as originally defined at Site C0012, suggesting that strata of Unit V (defined at Site C0011) are actually completely missing at Site C0012 (Figure 2 and Table 1). These revised age dates are sensible considering that Unit V at Site C0011 (= seismic unit "F" reported in Underwood et al., [2010]) abuts on a normal fault at the northern edge of the

\footnotetext{
${ }^{1}$ Additional supporting information may be found in the online version of this article.
}

Kashinosaki Knoll, and seismic unit $\mathrm{F}$ is missing on the knoll. Therefore, Unit IV at Site C0011 is equivalent to both Unit IVa and Unit IVb at Site C0012 (Figure 2 and Table 1). Heavy mineral composition shows a "Kumano component" (biotite, garnet, zircon, and apatite) in Unit IV at Site C0011 and Units IV + V at Site C0012 but a different, but unknown, source only in Unit $\mathrm{V}$ at Site C0011. Thus, we have merged Units IV and V as originally defined by Underwood et al. [2010] into Unit IV for Site C0012 (Figure 2 and Table 1).

[18] At Site C0012, an angular unconformity occurs at $\sim 510$ mbsf, with an apparent hiatus of $\sim 4 \mathrm{Myr}$ (Figure 2). Sandstones above the unconformity, some of which show cross laminae, plane-parallel laminae, convolute laminae, and soft sediment sheath folds, appear to have two separate detrital provenances: (1) a volcanic source with fresh volcanic glass, together with relatively large amounts of feldspar, and (2) a siliciclastic source enriched in sedimentary lithic grains, quartz, and heavy minerals (including pyroxene zircon and amphibole) (supporting information). Bulk X-ray diffraction (XRD) confirms that relative percentages of quartz and feldspar increase in the coarse-grained strata, and XRF data show appreciable scatter in most of the major oxides because of lithologic/textural heterogeneity. These sandstones are probably equivalent to those of Unit IV at C0011. Their ranges of compositions, textures, and ages are also reminiscent of those of the Miocene sand layers and volcaniclastic-rich deposits at ODP Site 1177 [Moore et al., 2001b; Fergusson, 2003; Underwood and Fergusson, 2005] (Figure 1).

[19] The lowermost sediments were not cored or logged at C0011, but at Site C0012, Unit VI 
(Figure 2 and Table 1) consists of a $9.3 \mathrm{~m}$ thick interval of variegated red, reddish-brown, and green calcareous claystone, rich in nannofossils, with minor amounts of radiolarian spines. Carbonate content in Unit IV is $\sim 20 \mathrm{wt} \%$ based on bulk powder $\mathrm{XRD}$ analysis. These pelagic sediments are early Miocene in age $(>18.9 \mathrm{Ma})$. The pelagic claystones accumulated in direct contact with igneous basement, and their mottled red-green coloration is probably due to iron reduction. On the basis of the nannofossils in the claystone, the Kashinosaki Knoll basaltic basement is older than 18.9 Ma.

\section{Seismic Stratigraphy}

[20] Ike et al. [2008a, 2008b] used seismic data to map the 3-D seismic facies distribution tied with ODP drill cores to document regional and local variations in basement relief, sediment thickness, and sediment type in the Shikoku Basin. Their trench-parallel seismic profiles showed three regional provinces in the Shikoku Basin that can be distinguished by the magnitude of basement relief and sediment thickness: designated western $(<200-400 \mathrm{~m}$ basement relief, $>600 \mathrm{~m}$ sediment thickness), central $(>1500 \mathrm{~m}$ relief, $\sim 2000 \mathrm{~m}$ sediments), and eastern $(<600 \mathrm{~m}$ relief, $\sim 1200 \mathrm{~m}$ sediments) provinces. The total thickness of sediment in basement lows is as much as six times greater than that over basement highs.

[21] The thicker accumulations of sediments $(\sim 1200 \mathrm{~m})$ over and around Kashinosaki Knoll [cf. Ike et al., 2008a] were confirmed by core-logseismic integration during IODP Expedition 322 (see figures F6 for Site C0011 and F34 for Site C0012). Figure 4a shows a line from the seismic reflection survey of Park et al. [2008] that crosses Sites C0011 and C0012 (Figures 4b and 4c show details discussed below). The lower portion of the sedimentary section has a package of highamplitude, continuous reflections (Figure 4a), shown by coring to include sediment gravity flow deposits (e.g., turbidites). Those intervals lap onto steep basement slopes but are parallel to the gentler basement slopes. The total sediment thickness on the western and northern slopes is $\sim 40-50 \%$ more than that on the summit and southeastern slopes of Kashinosaki Knoll. From these characteristics, we infer that the basal sedimentary section northwest of Kashinosaki Knoll accumulated by deposition from larger-

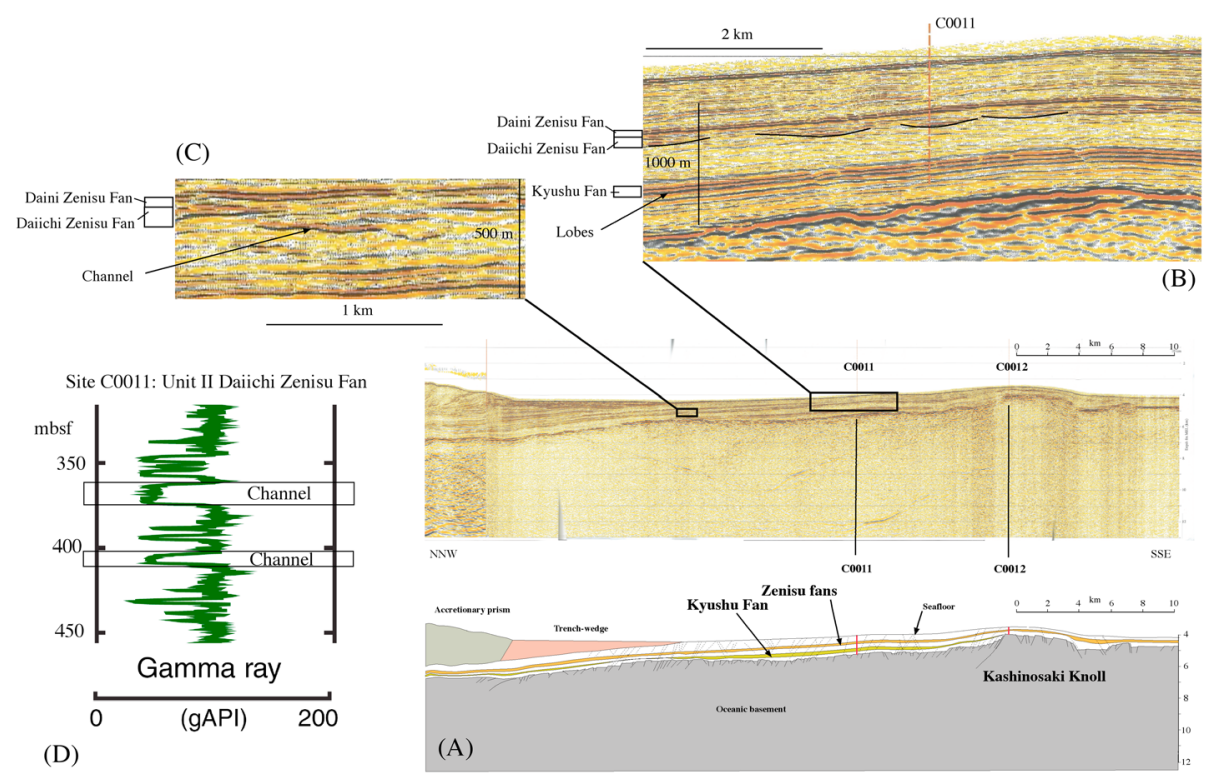

Figure 4. (a) Spliced composite seismic profile of a representative depth section from NanTroSEIZE 3-D data volume [Moore, 2009] and Line 95 from IFREE mini-3-D seismic survey [Park et al., 2008] that crosses Sites C0011 and C0012, and interpretation of main lithostratigraphic units. Enlargements of seismic sections show diagnostic depositional environments for the Kyushu and Zenisu submarine fans along this transect, including (b) sheet-like seismic character of Unit IV (Kyushu Fan), interpreted as distal outer fan lobe deposits, and (b and c) irregular seismic character of Unit IIB (Daiichi Zenisu Fan), interpreted as mainly volcanic sandstone filled, including MTD, submarine channel deposits, immediately overlain by a continuous, high-amplitude, seismic interval (Unit IIA), interpreted as unconfined, sheet-like volcanic sandstone deposits. (d) Logging while drilling (LWD) data show 10 to $20 \mathrm{~m}$ thick blocky gamma ray motif typical of many submarine channel fills. 
volume sediment gravity flows, such as turbidity currents, whereas the area southeast of Kashinosaki Knoll was dominated by hemipelagic sedimentation over asymmetric basement relief.

[22] The intervals with semitransparent to weak reflections (Figure 4a) correspond to mudstones that we interpret to originate from dilute hemipelagic suspensions (for example, Unit III hemipelagic facies). Of particular interest are the differences in acoustic character caused by intervals of sandy sediment gravity flow deposits. The cores and LWD data confirm that one interval of strong seismic impedance contrasts matches the coarse clastics of subunit IIb. The blocky log response (Figure 4d) and discontinuous reflector geometries (Figures $4 \mathrm{~b}$ and $4 \mathrm{c}$ ) are suggestive of submarine channels. We refer to that sandbody as the Daiichi Zenisu submarine fan, with channels on the order of 10 to $20 \mathrm{~m}$ in depth and 800 to $1000 \mathrm{~m}$ in width, similar in dimensions to many modern and ancient submarine channels [Clark and Pickering, 1996]. The basal part of the thickest channel fill consists of an $\sim 10 \mathrm{~m}$ thick MTD (400.86 to 411.15 mbsf at C0011). This chaotic deposit contains disaggregated pieces of volcaniclastic sandstone and bioturbated mudstone that show tight to isoclinal folding, thinning and attenuation of bedding, and subhorizontal small-scale faults with a normal (extensional) sense of displacement in the uppermost part. Interpretations of the seismic data suggest that these MTDs were erosive and responsible for channel incision (Figures $4 b$ and $4 c$ ). The map view channel orientation remains uncertain, something that cannot be resolved without a more extensive 3-D seismic grid. The features observed in Line 95 could be relatively straight channels coming from the east-northeast (subparallel to the trend of the trench axis) or sinuous channels coming from the north. This acoustic interval thins to the south but continues over the crest of Kashinosaki Knoll.

[23] Two additional distinct intervals of highamplitude reflections are more continuous when compared to Daiichi Zenisu Fan, suggestive of sheet-like flows. We refer to the youngest nonchannelized sandbody as the Daini Zenisu Fan. That relatively thin packet of reflections matches the coring interval with distinctive tuffaceous sediment gravity flow deposits (subunit IIa) and likewise continues over the crest of the basement high. The older interval of silty sediment gravity flow deposits (Unit IV) is also sheet-like (Figure 4), with an acoustic geometry suggestive of distal submarine fan (lobe and lobe fringe) deposits [e.g., Deptuck et al., 2008]. We designate Unit IV as the Kyushu Fan, and its equivalent packet of prominent reflections loses continuity near the edge of Kashinosaki Knoll. Unit IV appears to thin out almost completely against basement relief approximately $8-9 \mathrm{~km}$ north of Site C0011, but it may correlate with weak reflections observed under the trench wedge (Figure 4a). This geometry for the Kyushu Fan, showing thinning and onlap to both the south and north, suggests that it might have been supplied by sediment gravity flows moving oblique to the seismic line and infilling preexisting basement topographic lows, i.e., from a more westerly or easterly direction.

[24] The presence of sandbodies above Kashinosaki Knoll is interesting and perhaps surprising, because the thinning and onlap of older units against the knoll suggest that it was already an existing seafloor high [Ike et al., 2008a]. This observation requires either upslope flow [cf. Muck and Underwood, 1990; Pickering et al., 1992] or postdepositional uplift of the basement high. In contrast, Unit IV shows a substantial thinning toward Kashinosaki Knoll (also recognized by Ike et al. [2008a, Figure 4]) where it completely disappears on the downthrown side of a normal fault. This suggests that Kashinosaki Knoll had significant seafloor relief at least as early as the middle Miocene when the sediment gravity flow deposits of Unit IV began accumulating (i.e., $~ 14.0$ to 13.5 Ma). Also, the thinning out of Kyushu Fan against Kashinosaki Knoll and the continuity of the Zenisu Fan over the top, but not as horizontal bedding, favor tectonic rejuvenation and uplift of the knoll (estimated at $\sim 300 \mathrm{~m}$ of vertical uplift), probably in response to compressive forces as it approached the Nankai Trough.

\section{Detrital Provenance}

[25] Based on geographic proximity, the potential provenance of the sandstones in both the Kyushu and Zenisu Fans could be one or more of the following: SW Japan Arc to the north, Izu-Bonin Arc to the east, and for Unit II the Izu-Honshu Collision Zone. Plate tectonic reconstructions by Mahony et al. [2011] for the Shikoku Basin suggest that a considerable amount of sinistral strike slip associated with oblique subduction may have taken place during the late Miocene (see below), which opens up the intriguing possibility that many of the terrigenous sands were derived from a now-eroded landmass in the East China Sea prior to and during opening of the Sea of Japan. Westward continuation of the tectonostratigraphic belts of SW Japan (e.g., Shimanto, Sambagawa, and Ryoke belts) from Kyushu, via the Okinawa Islands, to north of Taiwan has been documented, for example, by Isozaki et al. 
[2010, Figures 1 and 10]. The sandy detritus in Kyushu Fan was likely eroded from sources similar to those of the Outer Zone of southwest Japan [e.g., Taira et al., 1989; Nakajima, 1997].

[26] Superficially similar sand deposits to those encountered at Sites C0011 and C012, and with overlapping ages, have been documented on the west side of the Shikoku Basin at ODP Site 1177 (Figure 5a) and DSDP Site 297 (Figures 5b and 6) [Karig et al., 1975; Harrold and Moore, 1975; Marsaglia et al., 1992, 1995; Fergusson, 2003; Underwood and Fergusson, 2005]. That Miocene dispersal system spread quartz-rich terrigenous sediment over a broad area of the Shikoku Basin [Moore et al., 2001; Fergusson, 2003]. Sand and sandstone samples from Site 1177 (occurring in four sandy intervals within Unit III; Fig. 5a), within the lower-upper Miocene lower Shikoku Basin deposits, typically contain $36 \%-47 \%$ quartz, $20 \%-30 \%$ feldspar, and $22 \%-43 \%$ lithic fragments [Fergusson, 2003]. Lithic fragments are dominantly of sedimentary type with a smaller quantity of silicic volcanic rock fragments $(2 \%-5 \%)$.

[27] At Site 297, a 247 m thick unit of sandy sediment gravity flow deposits was penetrated from 330 to $570 \mathrm{mbsf}$ (Figure 6). The age dating is relatively poor without continuous coring but suggests late middle Miocene to early Pliocene ages [Karig et al., 1975]. The composition of 28 sandstone samples averages $\quad$ quartz $_{14}$ feldspar $_{15}$ lithics $_{71}$ [Harrold and Moore, 1975]; the lithic fragments are predominantly sedimentary rock fragments, and the volcanic/lithic (V/L) ratio is quite low with an average of $0.09(\sigma=0.10)$. These sedimentary rock fragments are predominantly well rounded, equant to elongate grains containing quartz and feldspar in an argillaceous matrix. Mica, plant debris, and metamorphic grains are also present (polycrystalline quartz grains; probably metasedimentary). The low $\mathrm{V} / \mathrm{L}$ ratio, the high percentage of sedimentary rock fragments, and the presence of plant debris indicate that the sands were eroded from a continental source area with sedimentary parent rocks.

[28] Cessation of anomalous near-trench volcanism at $\sim 11 \mathrm{Ma}$ [Kimura et al., 2005] and subsequent erosion into the plutons and accreted sedimentary rocks resulted in a gradual change from smectite- to illitedominated clay mineral assemblages [e.g., Underwood and Fergusson, 2005; Guo and Underwood, 2012]. This temporal change in mineralogy supports an interpretation that a mainland terrigenous source provided substantial volumes of fine-grained sediment to these sites, even though the Izu-Bonin Arc was closer to the eastern side of the basin during the Miocene [Underwood et al., 2010]. Strengthening of the NE directed Kuroshio Current during the Pliocene may have also affected the direction of suspended sediment dispersal [Underwood and Fergusson, 2005].

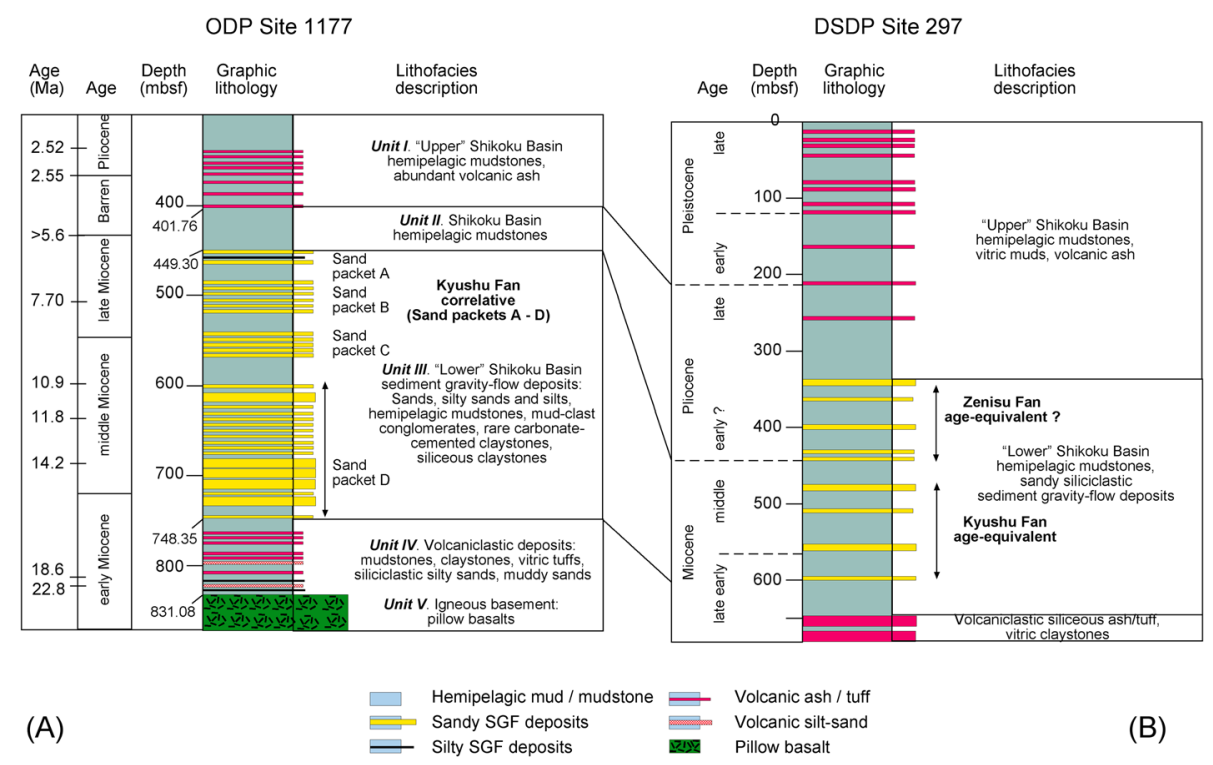

Figure 5. Summary lithologic logs for (a) ODP Site 1177 and (b) DSDP Site 297, also showing the approximate position of intervals of sand-rich sediment gravity flow deposits that are time equivalent to the Kyushu and Zenisu Fans at Site C0011 and C0012 as discussed in this paper (see Figure 1 for location). The inferred correlative sandy fans in IODP Sites C0011 and C0012 are also shown. Note that age dating at Sites 297 and 1177 is relatively poorly constrained compared with that at Sites C0011 and C0012. 


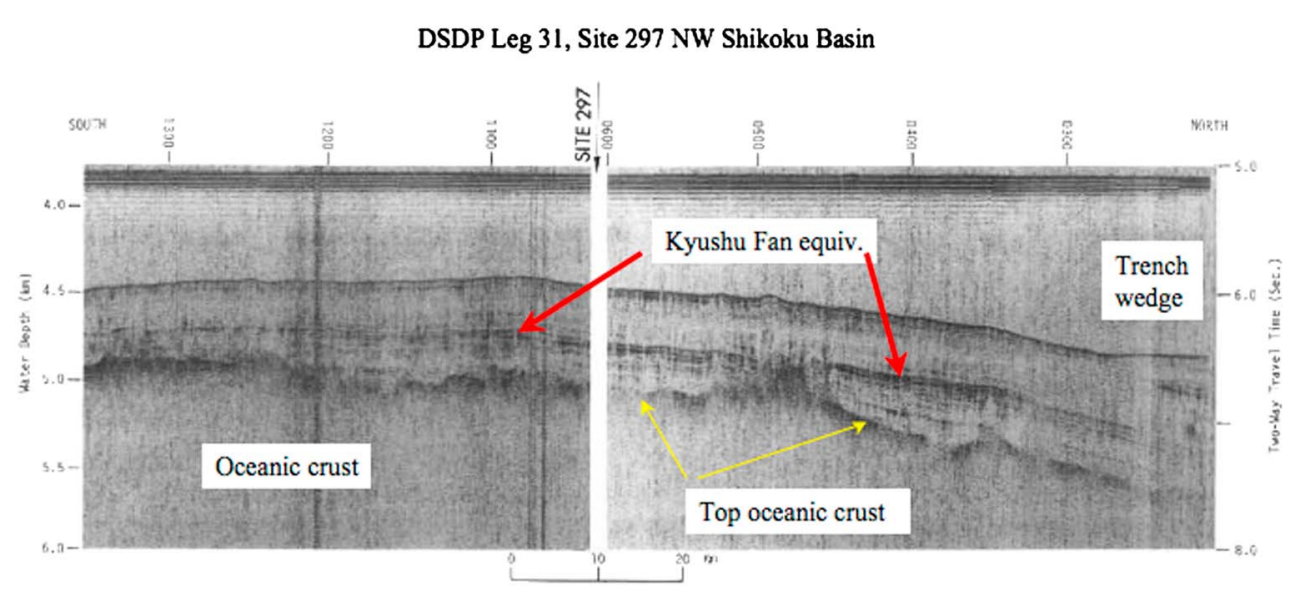

Figure 6. Seifu Maru (Maizuru Marine Observatory) reflection profile across the outer trench slope of the Nankai Trough and the NW Shikoku Basin through DSDP Site 297 (see Figure 1 for location). After Karig et al. [1975], the upper part of a $247 \mathrm{~m}$ thick unit of sandy sediment gravity flow deposits penetrated from 330 to 570 mbsf is shown by the arrow. Note the southward thinning and fining of the fan deposits (as inferred from their seismic character), believed to be coeval with the Kyushu Fan at Sites C0011 and C0012.

[29] To further constrain the sediment dispersal system, we have backtracked the paleogeographic positions of Sites C0011 and C0012 to 12 Ma based on estimated plate convergence rates of Kimura et al. [2005] of $4 \mathrm{~cm} / \mathrm{yr}$ to the NW from 0 to $4 \mathrm{Ma}$ and $0.9 \mathrm{~cm} / \mathrm{yr}$ to the NNW from 4 to $12 \mathrm{Ma}$ (Figure 7). That restoration places the location during Unit V deposition $\sim 350 \mathrm{~km}$ south of its present position.

\section{Implications for Bathymetry of Nankai Trough and Tectonic- Stratigraphic Evolution of Shikoku Basin}

[30] Plate reconstructions [Mahony et al., 2011; Hall, 2012] essentially place the northern Shikoku Basin, both its western and eastern parts separated by the Kinan seamount chain, adjacent to the East China Sea. If these reconstructions are correct, then the older Miocene Kyushu Fan was most likely supplied its clastic material through a submarine canyon/s west of Kyushu in what is now the northern East China Sea and possibly from an area of the SW Japan Arc between Kyushu and Shikoku (Figure 7a). The continuity of the Shimanto, Sambagawa, and other tectonostratigraphic belts of SW Japan west of Kyushu to somewhere northeast of Taiwan [Isozaki et al., 2010] does not, unfortunately, allow us to differentiate any further between these paleogeographic connections.

[31] A transport route through the East China Sea is supported by the presence of a very large and longlived sediment drainage system immediately west of Kyushu that includes extensive submarine canyons
[Oiwane et al., 2011, Figure 1]. At that time, the Okinawa Trough (Figure 7e) would not have blocked sediment delivery into the Shikoku Basin because that bathymetric obstacle did not form until 4-6 Ma [cf. Kimura, 1996; Miki et al., 1990; Lu and Hayashi, 2001; Yamaji, 2003; Expedition 331 Scientists, 2010]. Also, within the Xihu depression (Figure 7e) in the central and northern East China Sea, basin inversion occurred during the late Miocene. The entire Tertiary succession of nearly $10,000 \mathrm{~m}$ thickness underwent inversion, with removal of up to $1600 \mathrm{~m}$ of sedimentary strata in the north [Yang et al., 2011]. That erosional event probably contributed sediment influx to the Shikoku Basin.

[32] The Kyushu and Zenisu Fans were deposited when Sites C0011 and C0012 were positioned well to the south of the Nankai subduction front (Figure 7a). Broadly contemporaneous sands were drilled at DSDP Site 297 [Karig et al., 1975] and ODP Site 1177 [Moore et al., 2001a]. Those sediment gravity flow deposits were likely supplied from the same source area but through a more westerly supply route (Figure 7a). Coeval sands are not present, however, above the subducting basement high at ODP Sites 808, 1173, and 1174 [Underwood, 2007]. Blockage or deflection of flow paths by the Kinan seamount chain seems to demand separate transport routes to the Ashizuri transect sites versus the Kumano transect sites, split by the trend of the back-arc spreading ridge. Whether different submarine canyons supplied two coeval sandy fans or one route bifurcated on either side of the Kinan seamount chain remains unclear.

[33] The drainage systems that supplied the younger Zenisu Fans were probably similar to the present 

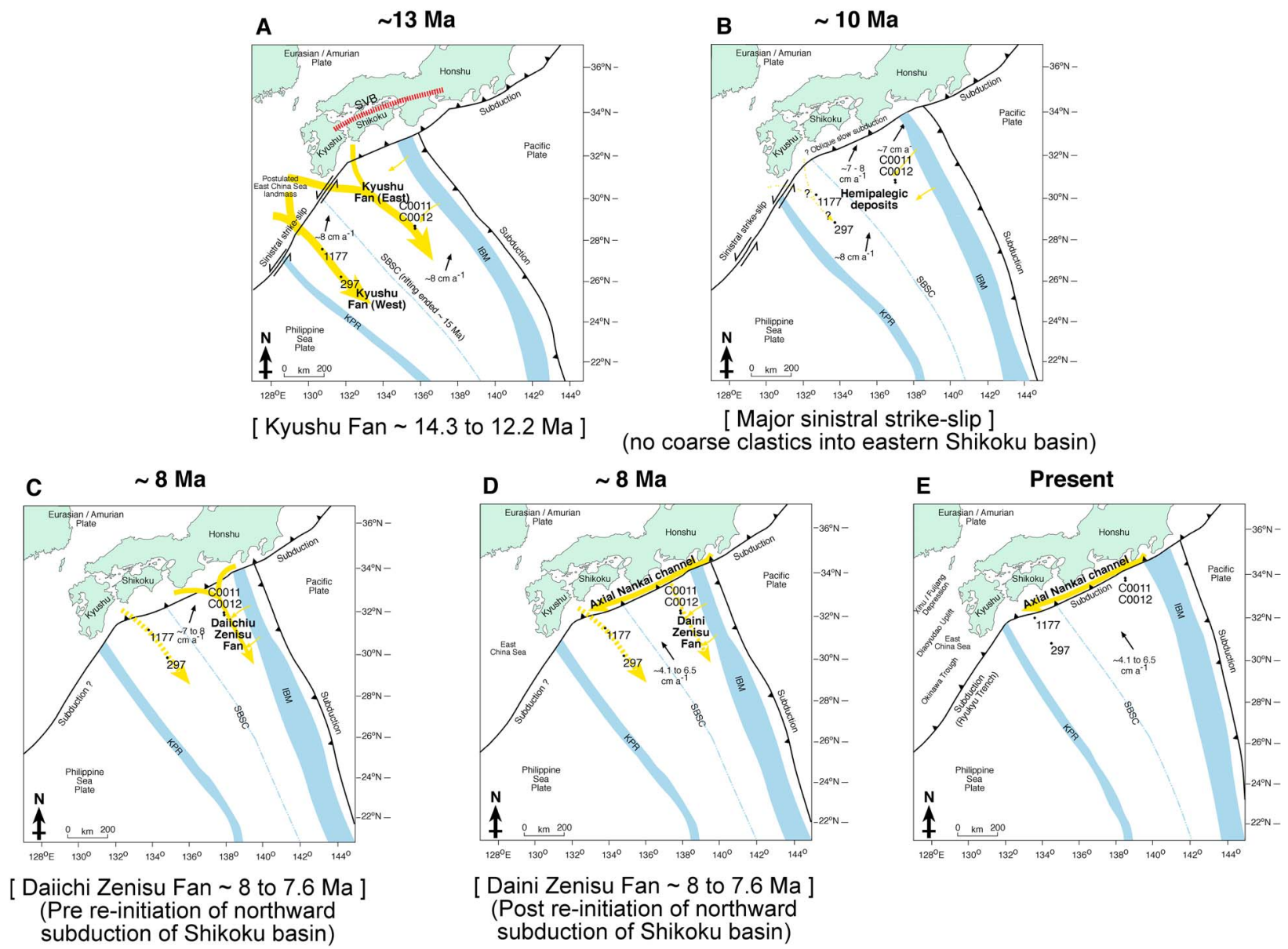

Figure 7. Schematic plate tectonic reconstructions for the Shikoku Basin and adjacent area, redrawn and modified from Mahony et al. [2011], to show the dispersal patterns for the coarse sandy sediments into the NE Shikoku Basin for (a) 13 Ma, (b) $\sim 10 \mathrm{Ma}$, (c) $\sim 8 \mathrm{Ma}$ immediately before renewed northward subduction, (d) $\sim 8 \mathrm{Ma}$, immediately after renewed northward subduction, and (e) present day. Parenthesis shows more precisely the time indicated within that range for the paleogeography. Thickness of sediment dispersal arrows indicates the relative importance of multiple sources. IBM=Izu-Bonin-Mariana Arc; SBSC=Shikoku Basin Spreading Center; KPR=Kyushu-Palau Ridge. $\mathrm{SVB}=$ subduction-related Setouchi Volcanic Belt (12.4 to $14.8 \mathrm{Ma}$ [Shimoda et al., 1998; Kimura et al., 2005]). Between 10 and $6 \mathrm{Ma}$, there is a lack of subduction-related volcanism [Mahony et al., 2011; Tatsumi, 2006], with subduction and arc volcanism ceasing 1-2 Myr earlier. Note the change in coarse sediment dispersal at $\sim 8 \mathrm{Ma}$, from submarine channels supplying sediment far out into the NE Shikoku Basin to axial trench (paleo-Nankai Channel), interpreted as the formation of a topographic trench as northward subduction of the Shikoku Basin oceanic crust resumed, picked up by arc volcanism 1-2 Myr later once the subducted slab had reached appropriate PTT (pressure-temperature-time) conditions conditions. The plate boundary configurations used for the 2 to 15 Ma reconstructions of SW Japan utilized published finite rotation poles for the Philippine Sea plate relative to Eurasia from Gaina and Müller [2007]. In these reconstructions, Japan is held fixed and the latitude and longitude are for present day Japan.

(Figures $7 \mathrm{~b}$ and $7 \mathrm{c}$ ), i.e., from a paleo-Fuji River and/or from further west via a paleo-Shionomisaki Canyon and other submarine canyons [Kawamura et al., 2009, Figure 1] or from multiple northern sources including the Izu collision zone via Suruga Trough. The Zenisu Fans were deposited during the later part of the so-called "slow subduction" tectonic stage of the Shikoku Basin below the SW Japan Arc (12 to $4 \mathrm{Ma}$ ), after sinistral strike-slip motion along parts of the plate boundary from 25 to $17 \mathrm{Ma}$ [Kimura et al., 2005]. The Mahony et al. [2011] reconstructions help explain an absence of subduction-related volcanism on Kyushu from 10 to $6 \mathrm{Ma}$, with increasing arc-like geochemistry after 6.5 Ma. They proposed sinistral strike slip off Kyushu as oblique subduction-accretion continued along much of the plate boundary with the Nankai Trough.

[34] Evidence for subduction-induced igneous activity was summarized by Kimura et al. [2005], who reinforced previous suggestions that anomalous 
near-trench magmatism commenced suddenly during rapid opening of the Sea of Japan and continued from 17 to $11-12 \mathrm{Ma}$. The opening of the Sea of Japan and clockwise rotation of the Outer Zone, therefore, coincide with deposition of the Kyushu submarine fan. This timing also matches a phase of rapid tectonic uplift in the Kyushu region (e.g., at $\sim 11 \mathrm{Ma}$ [Agar et al., 1989]). The Setouchi Volcanic Belt, which extends for more than $600 \mathrm{~km}$ along the northern side of Shikoku (Figure 3a), records high-Mg volcanism caused by continued subduction of young and hot Shikoku Basin lithosphere between $\sim 16$ and $11 \mathrm{Ma}$ [Kimura et al., 2005]. We see no evidence to suggest that Shikoku Basin deposits were derived from the Setouchi volcanic source.

[35] Mahony et al. [2011] suggested that sinistral strike-slip motion offshore southern Kyushu continued from 15 to $6 \mathrm{Ma}$, later than that in the reconstruction of Kimura et al. [2005]. They also noted that the 10 to $6 \mathrm{Ma}$ period is marked by a lack of arcrelated volcanism in the Kyushu region which led Kamata and Kodoma [1994] to suggest a hiatus in rapid orthogonal subduction. In any plate reconstruction, however, subduction-triggered volcanism lags 1-2 Myr behind subduction initiation to allow the downgoing slab to reach appropriate pressuretemperature conditions for melting. Those aspects are factored into our paleogeographies (Figure 7). Renewal of orthogonal subduction off Kyushu at $\sim 6 \mathrm{Ma}$, with an older subducting slab, probably led to the development of a bathymetric trench at the subduction front. Prior to that, however, the strikeslip or oblique slip character of the margin would be less likely to inhibit turbidity currents from flowing into the distal reaches of the Shikoku Basin.

[36] Channels of the Daiichi Zenisu Fan extended several hundred kilometers out into the Shikoku Basin, with length scales and dimensions similar to those of the present axial channel in the Nankai Trough (Figure 7) [Shimamura, 1989]. We see no evidence of large-scale levee development by aggradation but, rather, erosional-depositional channels (in the sense of [Normark, 1970]); i.e., there may be low-relief levee-overbank deposits not clearly imaged on the seismic line. The compelling evidence for these sediment gravity flows moving to the south comes from the petrography, not from the plate tectonic model or the seismic architecture; i.e., they contain terrigenous clastic material (above). The dimensions of these channels (hundreds of meters wide by several tens of meters deep), however, appear inconsistent with the small size of the Izu-Bonin islands, which would be less likely to sustain the required point sources of fluvial discharge as compared to larger paleowatersheds of central Honshu, or from the East China Sea area.

[37] Underwood and Fergusson [2005] identified three major sand petrofacies from ODP Leg 190 sites: (1) volcanic lithic sand in the Quaternary trench wedge (Site 1174) that was transported by axial flow from the Izu-Honshu collision zone, (2) quartzose sand in the Pliocene to early Pleistocene accretionary prism (Sites 1175 and 1176) that was transported through transverse canyons and channels, and (3) sedimentary lithic sand in the upper Miocene sections (Sites 1177 and 1178) that were also derived from the transverse delivery systems [cf. Underwood and Fergusson, 2005, Figure 9]. The abrupt transition that we documented from the channelized Daiichi Zenisu sediment gravity flow deposits to the nonchannelized Daini Zenisu Fan occurred at $\sim 8 \mathrm{Ma}$, which overlaps the time that the trench bathymetry began to form ( $\sim 6$ to $8 \mathrm{Ma}$ in Taira [2001] and Taira et al. [1992]). Mahony et al. [2011] suggested that changes in the Philippine Sea plate motion at $\sim 6.5 \mathrm{Ma}$ led to more rapid, nearly orthogonal subduction beneath Kyushu, a model supported by an increase in arc-like geochemistry of lavas since $\sim 6.5 \mathrm{Ma}$. They also favored initiation of Izu-Bonin and Honshu collision at 8-6 Ma. After the plate boundary became a more prominent bathymetric low, channelized flows down the trench axis were more likely deflected westward by the seaward trench slope. Only larger-volume (thicker) flows, including volcaniclastic flows, appear to have overtopped the confines of the trench to continue for several hundred kilometers as sheet-like beds (Figures $7 \mathrm{~b}$ and $7 \mathrm{c}$ ). No other late Miocene or Pliocene channel systems have been documented in the northeastern Shikoku Basin, so we propose that this important tectonic event helped confine coarse clastics to the trench floor after sufficient relief was created.

\section{Eustatic Control}

[38] Two stratigraphic intervals at Sites C0011 and C0012 contain appreciable amounts of coarse clastic detritus. The older is dated 12.2 to $13.8 \mathrm{Ma}$ (Kyushu Fan) and the younger Zenisu Fans are 7.6 to $9.1 \mathrm{Ma}$ [cf. Underwood et al., 2010]. These time intervals coincide with a prominent Neogene long-term fall in eustatic sea level as inferred from the oxygen isotope curve of Zachos et al. [2008] (Figure 8a). The Kyushu and Zenisu Fans can be correlated to the two inflection points on this long-term trend of accelerated cooling against a 


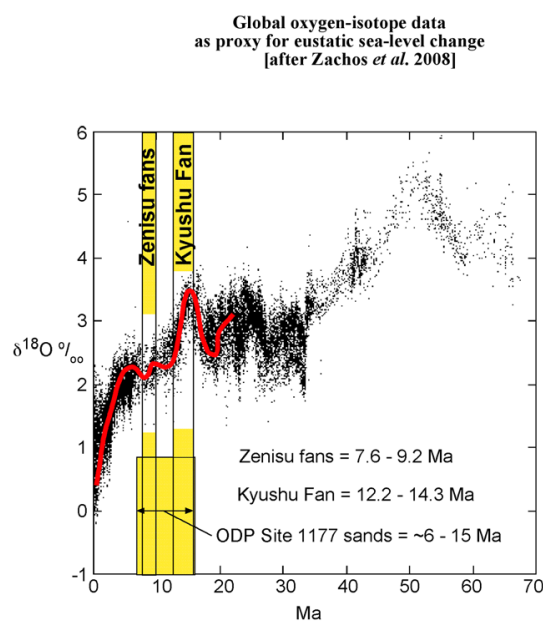

(A)

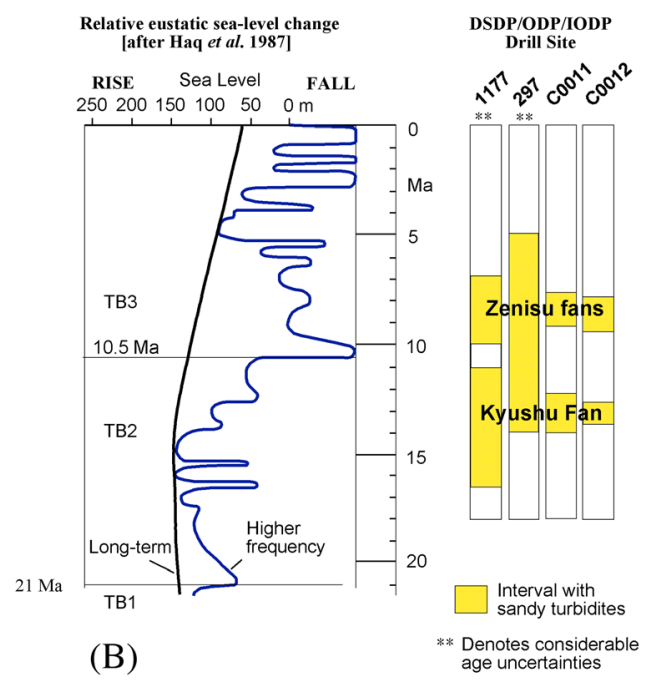

(B) ** Denotes considerable
age uncertainties

Figure 8. Timing of coarse sand supply into the Shikoku Basin at IODP Sites C0011 and C0012 and ODP Site 117: Site 297 is not shown as the age dating is relatively poor but appears to be similar to that in Site 1177. (a) Compilation of global $\delta^{18} \mathrm{O}$ record from benthic foraminifera as a proxy for global climate, ice volume, and relative eustatic sea level change over the past 70 Myr. Data replotted from Zachos et al. [2008]. (b) Timing of sand supply in relation to the eustatic curves of Haq et al. [1987]. Supercycle sequences defined by Haq et al. [1987] are indicated as TB1, TB2, and TB3. See text for explanation.

long-term eustatic fall in sea level (Figure 8a). Comparable events are seen on the sea level curve of Miller [2011, Figure 4] and the oxygen isotope record of Cramer et al. [2009].

[39] The Haq et al. [1987] eustatic curves show two lowstands at 13.8 and 12.5 Ma that are consistent with the timing of sand transport into the Shikoku Basin, but there is also a substantial lowstand associated with a supercycle boundary (TB2/TB3) at $10.5 \mathrm{Ma}$ (Figure $8 \mathrm{~b}$ ). Within the uncertainties of age dating, it is possible that sand accumulation continued into that time interval at Sites 297 and 1177 but not at Sites C0011 and C0012 where hemipelagic sedimentation occurred (Unit III). These differences can be reconciled with tectonic disruption of submarine canyon feeder system/s. The 8.2 Ma lowstand of Haq et al. [1987] is, however, consistent with sand accumulation at Sites C0011 and C0012 (Figure 8b), at a time when we believe that these sites were again linked to a submarine canyon feeder system/s. There is also a lowstand at $6.3 \mathrm{Ma}$, but by that time, the bathymetric depression of the trench was funnelling most of the terrigenous sand parallel to the trench axis.

[40] The synchroneity between some episodes of coarse clastic influx to the northeastern Shikoku Basin and some of the eustatic sea level falls inferred from the oxygen isotope proxy and Haq et al. [1987] curves suggests that glacioeustasy also exerted a significant influence on regional sedimentation. The absence of sands at Sites C0011 and C0012, when fine sand sediment gravity flow deposits were accumulating at ODP Site 1177, likely reflects both the considerable distance of these latter sites from the Honshu Arc $(\sim 300$ to $350 \mathrm{~km}$ south, based on realistic convergence rates as the Shikoku Basin crust was subducted) and that sand routing probably continued on the western side of the Kinan seamounts.

\section{Summary and Conclusions}

[41] Coring during IODP Expedition 322 showed how the depositional system of Shikoku Basin changed from an expanded (Site C0011) to a condensed section (Site C0012) in response to basement topography. Coring and logging also uncovered evidence of a previously unrecognized interval of late Miocene tuffaceous and volcaniclastic sandstones that we have designated the Daiichi Zenisu Fan (channelized, proximal) and immediately overlying Daini Zenisu Fan (sheet-like, distal). Older (early to middle Miocene) sediment gravity flow deposits with mixed detrital provenance (Kyushu Fan) are broadly correlative with superficially similar Miocene deposits at Sites 297 and 1177. Transport routes across the East China Sea must have extended $\sim 300 \mathrm{~km}$ into the Shikoku Basin based on backtracking of known plate motion vectors. Geochemical and petrographic data from the pumice fragments suggest a provenance to the north in the SW Japan Arc. The change from channelized to sheet-like flows occurred at $\sim 8 \mathrm{Ma}$. The 
bathymetric low of the Nankai Trough probably formed at about the same time, but axial channels deflected sediment routing away from the NE Shikoku Basin. Thick pyroclastic flows were still capable of traveling several hundred kilometers beyond the confines of the trench to deposit sheet-like deposits. There is no petrographic evidence to support the dominance of an axial flow trajectory farther to the west at Sites 1175, 1176, and 1178 [Underwood and Fergusson, 2005]. Thus, trench-parallel sediment routing did not become regionally dominant until the Pleistocene, after the collision between the Izu and Honshu volcanic arcs.

[42] Sinistral strike slip probably dominated the western parts of the Nankai subduction system in the late Miocene. When combined with oblique subduction, that paleotectonic regime means that the accreted sediments of late Miocene age were likely derived from a sediment source in the East China Sea. A long (3 Myr) interval of hemipelagic deposition (Unit III) corresponds to a time when coarse clastic supply was cut off from Sites C0011 and C0012 during sinistral strike slip and oblique/slow subduction farther east. At least some sands entered the western part of the Shikoku Basin when only hemipelagic deposits accumulated at Sites C0011 and C0012 in the eastern part of the basin. Such a scenario would be expected at a strike-slip plate margin where canyon supply routes were being cut off to starve some fans of terrigenous sediment (e.g., the Kyushu Fan at Sites C0011 and C0012) and reconfigure sediment routing so that more westerly sites (297 and 1177) continued to receive terrigenous sediment from a now-eroded landmass in the East China Sea.

[43] While we postulate that deep marine clastic sedimentation was strongly influenced by tectonic adjustments along the western and northern margins of the Shikoku Basin, we also note that the sand-rich intervals broadly coincide in age with some of the prominent Neogene long-term glacioeustatic lowstands [Zachos et al., 2008; Haq et al., 1987]. The supercycle lowstand boundary shown on the Haq et al. [1987] eustatic sea level curves at $10.5 \mathrm{Ma}$ does not express itself anywhere within the Shikoku Basin.

[44] Finally, recognition of submarine channels in the Zenisu Fan, as compared with more sheet-like submarine fan lobe deposits in the Kyushu Fan, means that potential migration routes for overpressured fluids will be different. For example, in sheet-like sands, pathways for fluid flow have greater horizontal permeability over hundreds to several thousand meters when compared with channel sands. In addition, sand-filled channels, acting as stratigraphic asperities typically on length scales of hundreds of meters and thicknesses of many tens of meters, may localize strain and deform in different ways than sheet-like sand geometries. Also, an inspection of the seismic line (Figure 3) suggests that the décollement in the Kumano transect may be localizing in Unit II (Zenisu Fan), and therefore, it is important to characterize and understand this newly recognized Shikoku Basin stratigraphic interval.

\section{References}

Agar, S. M., R. A. Cliff, I. R. Duddy, and D. C. Rex (1989), Accretion and uplift in the Shimanto Belt, SW Japan, J. Geol. Soc. London, 146, 893-896.

Ali, J. R., and S. J. Moss (1999), Miocene intra-arc bending at an arc-arc collision zone, central Japan: Comment, Island Arc, 8, 114-123.

Bilek, S. L., and T. Lay (2002), Tsunami earthquakes possibly widespread manifestations of frictional conditional stability, Geophys. Res. Lett., 29, 1673. doi:10.1029/2002GL015215.

Bilek, S. L., S. Y. Schwartz, and H. R. Deshon (2003), Control of seafloor roughness on earthquake rupture behavior, Geology, 31, 455-458.

Bredehoeft, J. D., R. D. Devanshir, and K. R. Belitz (1988), Lateral fluid flow in a compacting sand-shale sequence: South Caspian Basin, Am. Assoc. Petrol. Geol. Bull., 72, 416-424.

Clark, J. D., and K. T. Pickering (1996), Architectural elements and growth patterns of submarine channels: Application to hydrocarbon exploration, Am. Assoc Petrol. Geol. Bull., 80, 194-221.

Cloos, M. (1992), Thrust-type subduction-zone earthquakes and seamount asperities: A physical model for seismic rupture, Geology, 20, 601-604.

Cramer, B. S., J. R. Toggweiler, J. D. Wright, M. E. Katz, and K. G. Miller (2009), Ocean overturning since the Late Cretaceous: Inferences from a new benthic foraminiferal isotope compilation, Paleoceanography, 24, PA4216, doi:10.1029/ 2008PA001683.

Deptuck, M. E., D. J. W. Piper, B. Savoye, and A. Gervais (2008), Dimensions and architecture of late Pleistocene submarine lobes off the northern margin of East Corsica, Sedimentology, 55, 869-898.

Expedition 331 Scientists (2010), Deep hot biosphere. IODP Prel. Rept., 331. doi:10.2204/iodp.pr.331.2010

Expedition 333 Scientists (2011), NanTroSEIZE Stage 2: Subduction inputs 2 and heat flow. IODP Prel. Rept., 333.

Fergusson, C. L. (2003), Provenance of Miocene-Pleistocene turbidite sands and sandstones, Nankai Trough, Ocean Drilling Program Leg 190, in Proc. ODP, Sci. Results, edited by H. Mikada, G. F. Moore, A. Taira, K. Becker, J. C. Moore, and A. Klaus, pp. 1-28, 190/196, Ocean Drilling Program, College Station, TX.

Gaina, C., and R. D. Müller (2007), Cenozoic tectonic and depth/age evolution of the Indonesian gateway and associated backarc basins, Earth Sci. Rev., 83, 177-203. doi:10.1016/j.earscirev.2007.04.004. 
Guo, J., and M. B. Underwood (2012), Data report: Refined method for calculating percentages of kaolinite and chlorite from X-ray diffraction analysis, with application to the Nankai margin of southwest Japan, in Proc. IODP, edited by M. Kinoshita, H. Tobin, J. Ashi, G. Kimura, S. Lallemant, E. J. Screaton, D. Curewitz, H. Masago, and K. T. Moe, 314/315/316. IODP Management International Inc, Washington, DC, 843 doi:10.2204/iodp. proc.314315316.202.2012.offshore Japan: A summary of results from the NanTroSEIZE project.

Hall, R. (2002), Cenozoic geological and plate tectonic evolution of SE Asia and the SW Pacific: Computer-based reconstructions, model and animations, J. Asian Earth Sci., 20, 353-431.

Hall, R. (2012), Late Jurassic-Cenozoic reconstructions of the Indonesian region and the Indian Ocean, Tectonophysics, 570-571, 1-41.

Haq, B. U., J. Hardenbol, and P. R. Vail (1987), Chronology of fluctuating sea levels since the Triassic (250 million years ago to present), Science, 235, 1156-1167.

Harrold, P. J., and J. C. Moore (1975), Composition of deepsea sands from marginal basins of the northwestern Pacific, in Init. Repts Deep Sea Drilling Project, edited by D. E. Karig, et al., 31, 507-514, U.S. Government Printing Office, Washington DC.

Hibbard, J. P., and D. E. Karig (1990), Structural and magmatic responses to spreading ridge subduction: An example from SW Japan, Tectonics, 9, 207-230.

Ike, T., G. F. Moore, S. Kuramoto, J.-O. Park, Y. Kaneda, and A. Taira (2008a), Tectonics and sedimentation around Kashinosaki Knoll: A subducting basement high in the eastern Nankai Trough, Island Arc, 17, 358-375.

Ike, T., G. F. Moore, S. Kuramoto, J.-O. Park, Y. Kaneda, and A. Taira (2008b), Variations in sediment thickness and type along the northern Philippine Sea Plate at the Nankai Trough, Island Arc, 17, 342-357.

Isozaki, Y., K. Aoki, T. Nakama, and S. Yanai (2010), New insight into a subduction-related orogen: A reappraisal of the geotectonic framework and evolution of the Japanese Islands, Gondwana Res., 18, 82-105.

Kamata, H., and K. Kodoma (1994), Tectonics of an arc-arc junction: An example from Kyushu Island at the junction of the southwest Japan arc and the Ryukyu arc, Tectonophysics, 233, 69-81.

Kano, K., H. Kato, Y. Yanagisawa, and F. Yoshida (1991), Stratigraphy and geologic history of the Cenozoic of Japan, Rept. Geol. Surv. Japan, 274, 114.

Kawamura, K., Y. Ogawa, R. Anma, S. Yokoyama, S. Kawakami, Y. Dilek, G. F. Moore, S. Hirano, A. Yamaguchi, T. Sasaki, and YK05-08 Leg 2, and YK06-02 Shipboard Scientific Parties (2009), Structural architecture and active deformation of the Nankai Accretionary Prism, Japan: Submersible survey results from the Tenryu Submarine Canyon, Geol. Soc. Am. Bull., 121, 1629-1646.

Karig, D. E., et al. (1975), Initial Reports of the Deep Sea Drilling Project, 31, U.S. Government Printing Office, Washington, DC.

Kimura, J.-I., R. J. Stern, and T. Yoshida (2005), Reinitiation of subduction and magmatic responses in SW Japan during Neogene time, Geol. Soc. Am. Bull., 117, 969-986.

Kimura, M. (1996), Active rift system in the Okinawa Trough and its northeastern continuation, Bull. Disas. Prey. Res. Inst., Kyoto Univ., 45, 38-27.

Kobayashi, K., and M. Nakada (1979), Magnetic anomalies and tectonic evolution of the Shikoku inter-arc basin, in Geodynamics of the Western Pacific, edited by Uyeda, S.,
R. Murphy, and K. Kobayashi, 391-402, Japanese Scientific Society Press, Tokyo.

Lu, H., and D. Hayashi (2001), Genesis of Okinawa Trough and thrust development within accretionary prism by means of 2D finite element method, Structural Geology (J. Tectonic Res. Group Japan), 45, 47-67.

Mahony, S. H., L. M. Wallace, M. Miyoshi, P. Villamor, R. S. J. Sparks, and T. Hasenaka (2011), Volcano-tectonic interactions during rapid plate-boundary evolution in the Kyushu region, SW Japan, Geol. Soc. Am. Bull., 123, 2201-2223.

Marsaglia, K. M., R. V. Ingersoll, and B. M. Packer (1992), Tectonic evolution of the Japanese Islands as reflected in modal compositions of Cenozoic forearc and backarc sand and sandstone, Tectonics, 11, 1028-1044.

Marsaglia, K. M., S. Boggs, Jr., R. D. Clift, A. Seyedolali, and R. Smith (1995) Sedimentation in western Pacific backarc basins: New insights from recent ODP drilling, in, Active Margins and Marginal Basins of the Western Pacific, Geophys. Monograph 88, edited by B. Taylor and J. Natland, pp. 291-314, American Geophysical Union, Washington, DC.

Middleton, G. V., and M. A. Hamptonn (1973), Sediment gravity flows: Mechanics of flow and deposition, in Turbidites and Deep Water Sedimentation, edited by G. V. Middleton and A. H. Bouma (Co-Chairmen), 1-38, Society of Economic Paleontologists and Mineralogists, Pacific Section Short Course, Tulsa, Oklahoma.

Miki, M., T. Matsuda, and Y. Otofuji (1990), Opening mode of the Okinawa Trough: Paleomagnetic evidence from the South Ryukyu Arc, Tectonophysics, 175, 335-347.

Miller, K. G., G. S. Mountain, J. D. Wright, and J. V. Browning (2011), A 180-million-year record of sea level and ice volume variations from continental margin and deep-sea isotopic records, Oceanography, 24, 40-53. doi:10.5670/oceanog.2011.26.

Moore, G. F., et al. (2001a), New insights into deformation and fluid flow processes in the Nankai Trough accretionary prism: Results of Ocean Drilling Program Leg 190, Geochem. Geophys. Geosyst., 2. doi:10.1029/2001GC000166.

Moore, G. F., et al. (2001b), Proc. ODP, Init. Repts., 190, ODP, College Station, TX.

Moore, G. F. (2009), Structural and seismic stratigraphic framework of the NanTroSEIZE Stage 1 transect, in Proc. IODP, 314/315/316, edited by M. Kinoshita, H. Tobin, J. Ashi, G. Kimura, S. Lallemant, E. J. Screaton, D. Curewitz, H. Masago, and K. T. Moe, and the Expedition 314/315/316 Scientists, IODP Management Int. Inc., Washington, DC.

Muck, M., and M. Underwood (1990), Upslope flow of turbidity currents: A comparison among field observations, theory, and laboratory models, Geology, 18, 54-57.

Nakajima, T. (1997), Regional metamorphic belts of the Japanese Islands, Island Arc, 6, 69-90.

Normark, W. R. (1970), Growth patterns of deep-sea fans, Am. Assoc. Petrol. Geol., 54, 2170-2195.

Ogawa, Y., K. Horiuchi, H. Taniguchi, and J. Naka (1985), Collision of the Izu arc with Honshu and the effects of oblique subduction in the Miura-Boso Peninsulas, Tectonophysics, 119, 349-379.

Ogawa, Y., and H. Taniouchi (1988), Geology and tectonics of the Miura-Boso Peninsula and the adjacent area, Modern Geol., 12, 147-168.

Oiwane, H., S. Tonai, S. Kiyokawa, Y. Nakamura, Y. Suganuma, and H. Tokuyama (2011), Geomorphological development of the Goto Submarine Canyon, northeastern East China Sea, Mar. Geol., 288, 49-60. 
Okino, K., Y. Ohara, S. Kasuga, and Y. Kato (1999), The Philippine Sea: New survey results reveal the structure and the history of the marginal basins, Geophys. Res. Lett., 26, 2287-2290.

Otofuji, Y., A. Hayashida, and M. Torii (1985), When was the Japan Sea opened ?: Paleomagnetic evidence from Southwest Japan, in Formation of Active Ocean Margins, edited by N. Nasu et al., pp. 551-566, Terrapub, Tokyo.

Park, J.-O., T. Tsuru, T. No, K. Takizawa, S. Sato, and Y. Kaneda (2008), High-resolution 3D seismic reflection survey and prestack depth imaging in the Nankai Trough off southeast Kii Peninsula, Butsuri Tansa, 61, 231-241. (in Japanese, with abstract in English).

Pickering, K. T., M. B. Underwood, and A. Taira (1992), Open ocean to trench turbidity-current flow in the Nankai Trough: Flow collapse and reflection, Geology, 20, 1099-1102.

Piper, D. J. W., R. von Huene, and J. R. Duncan (1973), Late Quaternary sedimentation in the active eastern Aleutian trench, Geology, 1, 19-26.

Saffer, D., L. McNeill, E. Araki, T. Byrne, N. Eguchi, S. Toczko, K. Takahashi, and the Expedition 319 Scientists (2009), NanTroSEIZE Stage 2: NanTroSEIZE riser/riserless observatory, IODP Prel. Rept., 319.

Saito, S., M. B. Underwood, and Y. Kubo (2009), NanTroSEIZE Stage 2: Subduction inputs, IODP Sci. Prosp., 322.

Scholz, C. H., and C. Small (1997), The effect of seamount subduction on seismic coupling, Geology, 25, 487-490.

Sdrolias, M., W. R. Roest, and R. D. Müller (2004), An expression of Philippine Sea plate rotation: The Parece Vela and Shikoku Basins, Tectonophysics, 394, 69-86.

Shimamura, K. (1989) Topography and sedimentary facies of the Nankai deep sea channel, in Sedimentary Facies in the Active Plate Margin, edited by A. Taira and F. Masuda, 529-556, TERRAPUB, Tokyo.

Shimoda, G., Y. Tatsumi, S. Nohda, K. Ishizaka, and B.M. Jahn (1998), Setouchi high-Mg andesites revisited: geochemical evidence for melting of subducting sediments, Earth Planet. Sci. Lett., 160, 479-492.

Soh, W., K. T. Pickering, A. Taira, and H. Tokuyiama (1991), Basin evolution in the arc-arc Izu Collision Zone, Mio-Pliocene Miura Group, central Japan, J. Geol. Soc. London, 148, 317-330.

Taira, A. (2001), Tectonic evolution of the Japanese island arc system, Ann. Rev. Earth Planet. Sci. Lett., 29, 109-134.

Taira, A., H. Tokuyama, and W. Soh (1989), Accretion tectonics and evolution of Japan, in The Evolution of the Pacific Ocean Margins, edited by Z. Ben-Avraham, 100-123, Oxford Univ. Press, Oxford.

Taira, A., et al. (1992), Sediment deformation and hydrogeology of the Nankai Trough accretionary prism: Synthesis of shipboard results of ODP Leg 131, Earth Planet. Sci. Lett., 109, 431-450.

Takahashi, M., and K. Saito (1997), Miocene intra-arc bending at an arc-arc collision zone, central Japan, Island Arc, 6, 168-182.

Tamura, Y. et al. (2010), Missing Oligocene crust of the Izu-Bonin Arc: Consumed or rejuvenated during collision?, J. Petrol., 51, 823-846.
Tani, K., D. J. Dunkley, J.-L. Kimua, R. J. Wysoczanski, K. Yamada, and Y. Tatsumi (2010), Syncollisional rapid granitic magma formation in an arc-arc collision zone: Evidence from the Tanzawa plutonic complex, Japan, Geology, 38, 215-218.

Tatsumi, Y. (2006), High-Mg andesites in the Setouchi Volcanic Belt, Southwestern Japan: Analogy to Archean magmatism and continental crust formation?, Annu. Rev. Earth Planet. Sci., 34, 467-499.

Taylor, B. (1992), Rifting and the volcanic-tectonic evolution of the Izu-Bonin-Mariana arc, in Proc. ODP, Sci. Results, edited by B. Taylor, et al., 126, 627-651, ODP, College Station, TX.

Tobin, H. J., and M. Kinoshita (2006a), Investigations of seismogenesis at the Nankai Trough, Japan, IODP Sci. Prosp., NanTroSEIZE Stage 1.

Tobin, H. J., and M. Kinoshita (2006b), NanTroSEIZE: The IODP Nankai Trough Seismogenic Zone Experiment, Sci. Drill., 2, 23-27.

Underwood, M. B. (2007), Sediment inputs to subduction zones: Why lithostratigraphy and clay mineralogy matter, in The Seismogenic Zone of Subduction Thrust Faults, edited by Dixon, T., and J. C. Moore, 42-85, Columbia Univ. Press, New York.

Underwood, M. B., and G. F. Moore (1995), Chapter 5. Trenches and trench-slope basins, in Tectonics of Sedimentary Basins, edited by Busby, C. J., and Ingersoll, R.V., pp. 179-219, Blackwell Scientific Publishers, Oxford.

Underwood, M. B., and C. L. Fergusson (2005), Late Cenozoic evolution of the Nankai trench-slope system: Evidence from sand petrography and clay mineralogy, in Submarine Slope Systems: Processes, Products and Prediction, edited by Hodgson, D., and S. Flint, Geol. Soc. Spec. Publ., Bath.

Underwood, M. B., S. Saito, Y. Kubo, and the Expedition 322 Scientists (2010), Expedition 322 summary, in Proc. IODP, 322 , edited by S. Saito, M. B. Underwood, Y. Kubo, and the Expedition 322 Scientists, IODP Program Management Int. Inc., Tokyo.

Watts, A. B., and J. K. Weissel (1975), Tectonic history of the Shikoku marginal basin, Earth Planet. Sci. Lett., 25, 239-250.

Yamaji, A. (2003), Slab rollback suggested by latest Miocene to Pliocene forearc stress and migration of volcanic front in southern Kyushu, northern Ryukyu Arc, Tectonophysics, 364, 9-24.

Yamazaki, T., M. Yakahashi, Y. Iryu, T. Sato, M. Oda, H. Takayanagi, S. Chiyonobu, A. Nishimura, and T. Ooka (2010), Philippine Sea Plate motion since the Eocene estimated from paleomagnetism of seafloor drill cores and gravity cores, Earth Planet. Sci. Lett., 62, 495-502.

Yang, F.-L., X. Xu, W.-F. Zhao, and Z. Sun (2011), Petroleum accumulations and inversion structures in the Xihu depression, East China Sea Basin, J. Petrol. Geol., 34, 429-440.

Zachos, J. C., G. R. Dickens, and R. E. Zeebe (2008), An early Cenozoic perspective on greenhouse warming and carboncycle dynamics, Nature, 45, 279-283. 